$\begin{array}{ll} & \text { Etnográfica } \\ \text { etnográfica } & \text { Revista do Centro em Rede de Investigação em }\end{array}$

Antropologia

vol. 20 (3) | 2016

Vol. 20 (3)

\title{
Compassion between humans since when? What the fossils tell us
}

Compaixão entre humanos, desde quando? o que nos dizem os fósseis

\section{Eugénia Cunha}

\section{(2) OpenEdition}

\section{Journals}

Electronic version

URL: https://journals.openedition.org/etnografica/4734

DOI: 10.4000/etnografica.4734

ISSN: 2182-2891

\section{Publisher}

Centro em Rede de Investigação em Antropologia

\section{Printed version}

Date of publication: 1 October 2016

Number of pages: 653-657

ISSN: 0873-6561

\section{Electronic reference}

Eugénia Cunha, "Compassion between humans since when? What the fossils tell us", Etnográfica [Online], vol. 20 (3) | 2016, Online since 27 November 2016, connection on 10 February 2022. URL http://journals.openedition.org/etnografica/4734 ; DOI: https://doi.org/10.4000/etnografica.4734

\section{(c) (1) (8)}

Etnográfica is licensed under a Creative Commons Attribution-NonCommercial 4.0 International License. 


\title{
Compassion between humans since when? What the fossils tell us
}

\section{Eugénia Cunha}

\begin{abstract}
This paper explores the concept of compassion in an evolutionary framework, and presents pathological cases identified in fossil records. The paleopathological examples presented illustrate how the negative impact of disease and injury on individuals' lives is minimized through empathy, cooperation and care towards conspecifics.

KEYWORDS: compassion, paleopathology, paleoepidemiology, bioarcheology, human evolution.

Compaixão entre humanos, desde quando? O que nos dizem os fósseis Esta comunicação explora o conceito de compaixão, num contexto de estudo da evolução humana, através da apresentação de casos patológicos identificados no registo fóssil. Os exemplos paleopatológicos descritos mostram como o impacto negativo na vida dos indivíduos é minorado pela empatia, cooperação e cuidado para com os indivíduos doentes do grupo.

PALAVRAS-CHAVE: compaixão, paleopatologia, paleoepidemiologia, bioarqueologia, evolução humana.
\end{abstract}

CUNHA, Eugénia (cunha@antrop.uc.pt) - Departamento de Ciências da Vida, Centro de Ecologia Funcional, Universidade de Coimbra, Portugal.

THE IDEA OF THIS SHORT PAPER IS TO PROVIDE INSIGHT INTO THE antiquity of compassion (defined as a feeling of warmth and concern directed to another, and trying to make another suffer less and live easily) through looking for evidences of diseases in the fossil record which imply some kind of interpersonal help to guarantee the survival of the affected individual. This subject has always been an issue and its relevance can be witnessed by a recent book published on the "bioarcheology of care" (Tiley 2015).

The evidence of disease and disability in the fossil record is a partial way to research this question for two reasons: first, only some lives fossilize and we have access to a small portion of our ancestors; second, only some diseases leave traces on skeletal remains. Furthermore, the interpretation of traces is not an easy task. Only some pathologies can fossilize, and the older the human remains, the more difficult it will be to discriminate among taphonomic alterations and antemortem lesions. The detection of one case of a particular pathology does not allow conclusions to be drawn regarding its paleoepidemiology: the small size of many samples does not permit it. Hence, it does not make 
sense to discuss results in the context of "communities of past populations" since for the majority, sample sizes are too small. Above all, in paleopathology, the absence of evidence is not evidence of absence.

Identifying diseases in bones - mostly in fossilized bones - is not straightforward. In our evolutionary history, we have always been what we eat, and during 99\% of our history we were nomadic hunter-gatherers, with a lifestyle requiring high biomechanical effort and that resulted in reduced longevity. For example, this can be seen in the fossil record through an earlier eruption of the third molar and an earlier menopause which implies the low prevalence of some diseases such as osteoporosis. On the other hand, past hominins were more robust as evidenced by thicker cortical bone layers. Such examples highlight that reading hominin bones is not the same as reading present-day skeletal remains.

There are numerous pathological evidences in the fossil record. Within Australopithecus, the famous Lucy (3.4 million years ago) might have suffered from TMJ, temporo mandibular joint disease, and, eventually from Scheuermann disease (Cook et al. 1983). Within Paranthropus, no pathologies have been detected, with only isolated cases of interproximal caries, such as in a 1.5 million year old Paranthropus robustus.

Within the first Homo, some authors argue that KNM WT 15000 Turkana Boy, an 11-year-old boy who lived 1.6 million years ago, might have died of blood poisoning from a tooth infection, although further evidence is required to support this.

The first indication that hominins provided interpersonal help comes from Dmanisi, Georgia, with the first hominins outside of Africa. Indeed, the earliest toothless hominin in the world who lived 1.8 million years ago comes from Dmanisi (Lordkipanidze et al. 2005). The complete absence of teeth of D3444/D3900 means that he had survived for a lengthy period without consuming foods that required heavy chewing. Instead, he might have consumed soft foods and might have had the help from other individuals. This case raises important questions about hominin social structures. Other examples in early Homo, such as KNM ER 1808 Homo ergaster, 1.6 million years ago, who possibly suffered from hypervitaminosis (Walker, Zimmerman and Leakey 1982), does not help to build a picture of interpersonal relations, but mainly raises questions on Homo diet.

Even the well-known case of Pithecanthropus III, from Java, displaying a traumatic miosistis ossificans, an evident bone exostosis in the femur, does not necessarily imply the help of a second person to survive. Much later, the female skull from la Salé-Marocco (from around 400 thousand years ago) represents a possible case of congenital torticollis, a congenital abnormality which limited the movements of the head and limbs and might have implied some interpersonal help to survive, but nothing significant. This case was considered a "product of evolved altruism" by Hublin (2009: 6430). 
The famous Middle Pleistocene fossil treasure of Atapuerca, Miguelon (skull 5), Sima de los Huesos, from 400 thousand years ago, might have died from septicemia, a generalized infection which, in this case, might have started in the dentition. Septicemia is always a quick process and does not have major implications in terms of social care. Skull 14 from Sima de los Huesos (Gracia et al. 2009) shows craniosinostosis, early suture closure, which informs our understanding of compassion in the Middle Pleistocene. The survival of an individual with this disease until the age of $1 \mathrm{l}$ years has some implications in terms of sociobiological behavior, such as help from family members. It is the oldest evidence in human evolution of a very rare pathology, which implies, among others, some motor/cognitive problem.

Before arriving to Neanderthals, maybe only the skull KNM ES 11693 (Eliye Springs skull, Lake Turkana), with an age of 200-300 thousand years, displays cranial thickness and exocranial porosity in relation with chronic anaemia (Bräuer et al. 2003).

Neanderthals are well known, among other things, because of their burials and symbolic behavior, and therefore it is not surprising to find evidence of interpersonal help. There are some examples of pathologies, such as the cases of La Ferrassie, with osteoartrosis and deformation at the level of postcranial skeleton and even a case of an eventual systemic disease, or La Chapelle aux Saints (Dawson and Trinkaus 1997), with several degenerative diseases, which tell us that these hominins lived longer than would be expected based on their condition and were accepted by their communities.

The mandible of Aubesier 10, a case from the Middle Pleistocene, with serious abnormalities and implications for masticatory function (Lebel and Trinkaus 2002) gave rise to an interesting discussion about the existence of conspecific care (DeGusta 2003), emphasizing the difficulty to infer that from pathological evidences.

Perhaps the most famous pathological case within Neanderthals is Shanidar 1, with a traumatic injury on the left orbit which might have caused blindness and multiple fractures to the skull and postcranial bones. Mostly, the disuse atrophy of the right arm is consistent with paralysis, which tells us that this handicapped individual was living in a society (Conrad and Richter 2011 ).

All the other cases of lesions reported for Neanderthals, including DISH (Shanidar) (Crubézy and Trinkaus 1992), healed fractures (Krapina and St. Cesaire) and even the enthesopathies for Kiik Koba, are not relevant to make inferences about compassion in early humans (Trinkaus, Maley and Buzhilova 2008).

Finally, among the first modern humans, Qafzeh 12 (Tillier et al. 2001) refers to a case of hidrocephaly in a three-year-old child, who would never arrive to that age without family support. The well-known Cro-Magnon, 
namely skeleton 1, displays an erosion of the vertical part of the frontal bone which might be due to histiocitosis X, a quite rare pathology (Thillaud 1996). The "earliest known case of dwarfism in the human record" is El Romito 2, which provides "evidence of tolerance of, and care for, a severely deformed individual in the Palaeolithic" (Frayer et al. 1987: 61). Lastly, skeletal remains of Homo floresiensis, despite his small brain and large feet, have not been particularly informative about the bioarchaeology of care.

In all, "the use of pathologies to infer conspecific care is neither original nor straightforward" (Dettwyler 1991: 380). To infer conspecific care on the basis of lesions and pathologies is not warranted and some individuals might have survived with no external help from the others (Hublin 2009). More comparative studies are needed (DeGusta 2002).

Above all, social functions are also a product of our large brain and cooperative behavior, and pair bonding among other things. As these behaviors are observed in extant nonhuman primates (Cuozzo and Sauther 2004; Hublin 2009), then, why would we not expect to see them in past homins? The recent case reported by Matsumoto et al. (2015) about the interactions between a severely disabled infant chimpanzee and her mother, in the wild, is a good illustration of how much nonhuman primates care about each other, even when disabled. Inferring care in past hominins is a challenge which requires evidence from several sources to be validated.

\section{REFERENCES}

BRÄUER, Günter, et al., 2003, "Pathological alterations in the archaic Homo sapiens cranium from Eliye Springs, Kenya”, American Journal of Physical Anthropology, 120 (2): 200-204. CONARD, Nicholas, and Jürgen RICHTER, 201 1, Neanderthals Lifeways: Subsistency and Technology. Tubingen, Springer.

COOK, Della Collins, et al., 1983, "Vertebral pathology in the Afar australopithecines", American Journal of Physical Anthropology, 60 (1): 83-101, DOI: 10.1002/ajpa.13306001 13. CRUBÉZY, Eric, and Erik TRINKAUS, 1992, "Shanidar 1: A case of hyperostotic disease (DISH) in the middle paleolithic", American Journal of Physical Anthropology, 89 (4): 411 -420 .

CUOZZO, Frank, and Michelle SAUTHER, 2004, "Tooth loss, survival, and resource use in wild ring-tailed lemurs (Lemur catta): implications for inferring conspecific care in fossil hominids", Journal of Human Evolution, 46 (5): 623-631.

DAWSON, James E., and Erik TRINKAUS, 1997, "Vertebral osteoarthrithis in La Chapelle aux Saints I Neanderthal”, Journal of Archaeological Science, 24: 1015-1021. 
DeGUSTA, David, 2002, "Comparative skeletal pathology and the case for conspecific care in Middle Pleistocene hominids", Journal of Archaeological Sciences, 29 (12): 1425-1438.

DeGUSTA, David, 2003, "Aubesier 11 is not evidence of Neanderthal conspecific care", Journal of Human Evolution, 45 (1): 91-94.

DETTWYLER, Katherine Anne, 1991, "Can paleopathology provide evidence for 'compassion'?", American Journal of Physical Anthropology, 84 (4): 375-384.

FRAYER, David W., et al., 1987, "Dwarfism in an adolescent from the Italian Late Upper Paleolithic”, Nature, 330: 60-62.

GRACIA, Ana, et al., 2009, "Craniosinostosis in the Middle Pleistocene human Cranium 14 from the Sima de los Huesos, Atapuerca, Spain", Proceedings of the National Academy of Sciences of the United States of America (PNAS), 106 (16): 6573-6578.

HUBLIN, Jean-Jacques, 2009, "The prehistory of compassion", Proceedings of the National Academy of Sciences of the United States of America (PNAS), 106 (16): 6429-6430.

LEBEL, Serge, and Erik TRINKAUS, 2002, "Middle Pleistocene human remains from the Bau de l'Aubesier", Journal of Human Evolution, 43 (65): 659-685.

LORDKIPANIDZE, David, et al., 2005, “The earliest toothless hominin skull”, Nature, 434: 717-718.

MATSUMOTO, Takuya, et al., 2015, "An observation of a severely disabled infant chimpanzee in the wild and her interactions with her mother", Primates, 57 (1): 3-7.

THILlaud, Pierre, 1996, Paléopathologie Humaine. Paris, Kronos BY Editions.

TILEY, Lorna, 2015, Theory and Practice in the Bioarchaeology of Care: Bioarchaeology and Social Theory. London, Springer.

TILLIER, Anne-Marie, et al., 2001, "Brief communication: an early case of hydrocephalus the Middle Paleolithic Qafzeh 12 child (Israel)", American Journal of Physical Anthropology, 114 (2): 166-170.

TRINKAUS, Erik, Blaine MALEY, and Alexandra P. BUZHILOVA, 2008, "Brief communication: paleopathology of the Kiik-Koba 1 Neandertal”, American Journal of Physical Anthropology, 137 (1): 106-112.

WALKER, Alan, Michael R. ZIMMERMAN, and Richard E. F. LEAKEY, 1982, "A possible case of hypervitaminosis A in Homo erectus", Nature, 296: 248-250. 